\title{
LUIS DE MOLINA Y EL HUMANISMO JURÍDICO DE LA ESCUELA DE SALAMANCA
}

\author{
Guillermo José MAÑón GARIBAY*
}

\begin{abstract}
SUMARIO: I. Introducción. II. Antecedentes de la Reforma protestante. III. Reforma y contrarreforma. IV. El humanismo jurídico de Luis de Molina. V. Conclusiones: la hora de Dios en el Nuevo Mundo.
\end{abstract}

\section{INTRODUCCIÓN}

En el horizonte espiritual del siglo XVI destaca, junto con el movimiento del humanismo y Renacimiento, el descubrimiento y conquista de América. Es una época de cambios y transformaciones en la visión y mentalidad del mundo europeo, que llevó a los historiadores a considerar el término e inicio de una nueva era, conocida hoy como Moderna.

Cada pueblo hizo frente a las múltiples transformaciones con las herramientas intelectuales a su disposición; por ejemplo: en Italia, con las ideas neoplatónicas de Pico della Mirandolla (1463-1494) y Marsilio Ficino (1433-1499), y en España, con las ideas aristotélico-tomistas presentes principalmente en Francisco de Vitoria (1483-1546) y Domingo de Soto (1494-1560; por ejemplo, la Escuela de Salamanca). Es común decir que hubo una vuelta a los modelos grecolatinos de la Antigüedad con el fin de gestar una nueva concepción del hombre y su mundo, que estuviera a la altura de los tiempos.

* Licenciado, maestro y doctor en filosofía. Investigador en el Instituto de Investigaciones Jurídicas de la UNAM. 
¿Qué tiempos? el cisma de Occidente, la guerra de los cien años, la anarquía feudal, la crisis económica, la decadencia de la escolástica, la disminución de los ideales religiosos, todos fueron factores decisivos para el desarrollo de un nuevo humanismo jurídico a lo largo y ancho de Europa occidental. Mientras los humanistas italianos ensayaron una visión del hombre y su mundo desgajada del orden sobrenatural, los teólogos salmantinos continuaron fieles a la directriz medieval de considerar al hombre en su perspectiva religiosa; tanto Vitoria como Soto (y el resto de sus discípulos) partieron de la filosofía de santo Tomás para dar respuesta a los problemas planteados por la conquista de América. Por ello, todos penetraron en la nueva problemática sin dejar la teología, aunque forzados, ciertamente por la nueva realidad, a considerar la civilización cristiana de su tiempo como un momento histórico dado, y elaborar estrategias para la aplicación de la doctrina universal a los problemas concretos de su época.

Para muchos historiadores, la Escuela de Salamanca inaugura una nueva antropología filosófica desde el momento en que se vio compelida a preguntarse qué es el hombre y cuáles los valores humanos y cristianos (libertad y gracia divina), con el fin de definir una postura respecto a la controversia de Valladolid (1550-1551) y la Reforma protestante (1517-1521). Domingo de Soto redactó su libro De natura et gratia para inspirar a los religiosos del Concilio de Trento (1545-1563) y fijar una postura frente a las insidias de los reformadores (Lutero y Calvino). Su idea sobre la libertad del hombre y la función de la gracia divina, necesaria para su salvación, influyeron en todos los pensadores de su época. Mientras el corolario de la Junta de Valladolid siguió nutriendo el corpus jurídico de las Leyes de Indias, el Concilio de Trento apadrinó el movimiento de Contrarreforma abanderado por el español Ignacio de Loyola y la Compañía de Jesús (1534). A ésta perteneció el insigne Luis de Molina (1535-1600), heredero de las preocupaciones y enseñanzas de la Escuela de Salamanca, y quien desarrolló una nueva concepción del humanismo jurídico.

A continuación, se presentarán los antecedentes históricos del pensamiento jurídico de Molina (Reforma y Contrarreforma), para después exponer su idea de libertad y responsabilidad del nuevo orden social en el Nuevo Mundo.

\section{AnteCEDENTES DE LA Reforma PRotestante}

La Reforma protestante, incoada el 31 de octubre de 1517, con la adhesión de las 95 tesis a la entrada de la catedral de Wittenberg, tiene múltiples an- 
tecedentes que explican finalmente el cisma de la Iglesia de Occidente y sus repercusiones jurídicas y sociales.

Las 95 tesis se refieren a cuestiones principalmente teológicas ${ }^{1}$ (la gracia divina y el sincero arrepentimiento frente a la remisión de los pecados a través de la compra de indulgencias plenarias) y fueron condenadas por el obispo de Maguncia y el papado con base en argumentos teológicos. Sin embargo, sus secuelas rebasaron el ámbito teológico porque fueron espoleadas por acontecimientos fuera de dicho orden.

Martín Lutero (1483-1546), monje agustino, atizó con sus tesis un debate teórico como hubo tantos en el pasado; por ello vale preguntar por qué éste en particular tuvo un impacto cismático. Ciertamente, como todo suceso de la historia, es difícil explicar de manera absolutamente satisfactoria el porqué de la Reforma; no obstante, valgan las siguientes razones como una aproximación para discernir el éxito de Lutero frente a otros quejosos anteriores a él, como el inglés Juan Wyclif (1320-1384), el checo Jan Hus (1370-1415) o su contemporáneo suizo Ulrico Zwinglio (1484-1531).

\section{Los cambios}

Un alud de vicisitudes de toda índole creó un ambiente propicio para la Reforma luterana, entre éste cabe mencionar: a) La revolución del humanismo renacentista (s. XIV y XV) y los cambios sociales inducidos por los movimientos heréticos de los siglos XII y XIII contra la Iglesia; $b$ ) La revolución científica emprendida por Nicolás Copérnico (1473-1543), Galileo Galilei (1564-1642) y Johannes Kepler (1571-1630), que culminó con el paradigma científico del mecanicismo; c) La revolución política de Nicolás Maquiavelo (1469-1527); d) La revolución económica del mercantilismo, con lo que se da inicio a la economía capitalista, y e) La revolución axiológica del manierismo y las expediciones marítimas, el invento de la imprenta y la pólvora.

\section{La revolución del humanismo renacentista}

El término humanismo fue acuñado por el historiador alemán Friedrich Niethammer a principios del siglo XIX para referirse con él a la actitud levantisca de intelectuales como Francisco Petrarca, Erasmo de Róterdam,

1 Sobre Martín Lutero y la Reforma protestante, véase Kaufmann, Thomas, Geschichte der Reformation, Frankfurt am Main, Suhrkam Verlag, 2009. 
Luis Vives, Tomás Moro o Michel de Montaigne, frente al estancamiento de la escolástica tardía y el control por parte de Iglesia de los centros de enseñanza, especialmente las universidades. Con ello se deseaba impulsar el desarrollo intelectual a partir de elementos de la cultura pagana (por ejemplo, antigüedad grecorromana versus cristiana) y conquistar así la libertad intelectual respecto del yugo eclesiástico. ${ }^{2}$

El objeto de reflexión sería lo humano, y no más lo divino, y tendría como lugar de nacimiento Italia, donde persistían los vestigios arqueológicos de la cultura antigua y, sobre todo, donde gracias al comercio marítimo se había formado una clase burguesa que patrocinaría a los nuevos intelectuales. Su difusión tuvo lugar fuera de las universidades pontificias, dentro de las recién fundadas academias (en remembranza de la Academia de Platón, cerrada por Justiniano en 529 d. C.) y utilizando la lengua vernácula para fomentar la independencia del latín (lengua de la Iglesia). Precisamente por esto último se puso a la cabeza del movimiento Francesco Petrarca (1304-1374), al escribir en lengua italiana, investigar la literatura pagana y editar los textos de Cicerón. Vale aquí traer a la memoria que en tiempos pasados habían sido condenados por herejes los movimientos de Pedro Valdo (1140-1205) y los hermanos del libre espiritu (siglo XIII), ${ }^{3}$ quienes predicaron en lengua vernácula en las plazas públicas, y que la traducción de la Biblia al alemán fue una forma de insubordinación por parte de Martín Lutero y Philipp Melanchthon.

La difusión del espíritu del humanismo no sólo estuvo a cargo de un puñado de sabios, academias y bibliotecas establecidas entre los siglos XIV y XV, sino también propiciada por los viajes y expediciones. Ya en el siglo XIII, Marco Polo (1254-1324) había viajado a la China de Kublai Kahn $\mathrm{y}$ al regresar refirió las maravillas que excitaban a cualquier comerciante; pero los viajes de expedición no iniciaron sino hasta un siglo más tarde con Vasco de Gama (1469-1524), Fernando de Magallanes (1480-1521), Cristóbal Colón (1451-1506) y Martín, Vicente y Francisco Pinzón (14411514), quienes buscaban no solamente comerciar, sino ensanchar la visión del hombre y el mundo.

Todo esto resulta incompleto si no se menciona la doctrina de la "doble verdad", adjudicada al musulmán Averroes (1126-1198) y en franca oposi-

2 Sobre el tema del yugo eclesiástico en el humanismo, Renacimiento y reformación, véase Schorn-Schütte, Luise, Die Reformation, Vorgeschichte, Verlauf, Wirkung, München, C. H. Beck Verlag, 2016.

3 Sobre los movimientos heréticos, véase Grundmann, Herbert, Religiöse Bewegungen im Mittelalter, Darmstadt, Vitorio Klostemann, 1974. 
ción a Tomás de Aquino (1225-1275); porque Averroes, y los averroístas latinos del siglo XIII, afirmaban que había dos verdades: una para la religión y otra para la ciencia, mientras santo Tomás sostenía una sola, donde los hallazgos de las ciencias tenían que coincidir con las sentencias de la religión. No era posible la autonomía de la ciencia sin una dispensa para contradecir las interpretaciones bíblicas del pasado, y ésta se concedía a través de la asunción de una "doble verdad".

\section{La revolución científica}

A lo largo de toda la Edad Media prevaleció la visión aristotélico-ptolemaica del universo, según la cual la tierra era el centro de universo, este modelo fue incuestionado y adoptado por todos los doctores de teología, como Tomás de Aquino, canonizado en 1323. Como apuntalamiento a la concepción geocéntrica del universo, estaba la correspondencia entre el macro y el microcosmos que establecía un centro y una periferia jerárquicas: en el caso de la Iglesia, el centro lo ocupaba el papa y en la periferia los demás prelados y feligreses; en el caso del poder civil, el centro lo ocupaba el rey y en la periferia los súbditos, fueran aristócratas o no; en el caso de la familia, el centro lo ocupaba el padre y la periferia sus demás miembros. Esta correspondencia macro-microcosmos revelaba la armonía universal y la conexión de todo con todo gracias a una inteligencia superior. Todo giraba alrededor de la tierra, no sólo porque así lo afirmaba Aristóteles y Ptolomeo, sino también porque el planeta era el culmen de la creación divina (por ejemplo, habitada por el hombre, imagen divina), porque allí había tenido lugar la "historia sagrada" (nacimiento, predicación, pasión, muerte y resurrección del Cristo) y porque allí tendría lugar la "edad del Espíritu Santo", siguiendo a la del padre y la del hijo, según Joaquín de Fiore. ${ }^{4}$

Los hallazgos astronómicos de Nicolás Copérnico ${ }^{5}$ desfondaron la visión aristotélico-ptolemaica del universo, a la vez que toda la concepción social, civil y eclesiástica, porque desfiguraba la relación macro-microcosmos. Pero también contravenía la forma de entender o interpretar la evidencia empírica: quien observa la bóveda celeste tiende naturalmente a pensar que la tierra es el centro del universo, ¿y cómo convencernos del movimiento

4 Sobre Joaquín de Fiore, véase Grundmann, Herbert, Studien über Joachim von Floris, Leipzig, Teubner Verlag, 1926.

5 Sobre la "Revolución copernicana", véase Blumenberg, Hans, Die Genesis der Kopernikanischen Welt, Frankfurt am Main, Suhrkamp, 1975. 
rotario del planeta, si nuestros sentidos no perciben movimiento alguno? El dicto aristotélico "el conocimiento comienza por la experiencia sensorial", se debilitaba ante los estudios copernicanos y abría la puerta al racionalismo cartesiano, que desconfiaría de los sentidos e intentaría enderezar no sólo la visión del universo, sino también la del conocimiento mismo. La nueva fundamentación del conocimiento abandonaría la explicación aristotélica vía clasificación por género y diferencia específica, a la vez que traería consigo el paradigma explicativo vía enunciados universales, por ejemplo, la postulación de leyes que rigen de manera inexorable los fenómenos naturales, a la manera del mecanismo de un reloj (en palabras de Kepler). Por ello, el nuevo modelo científico se llamaría "mecanicismo". ${ }^{6}$

\section{La revolución política}

El Príncipe de Nicolás Maquiavelo es el texto que inaugura una nueva forma de hacer política, porque recomienda al gobernante no actuar bajo ninguna otra máxima que aquella que le asegure el control del poder político. Desde aquí, la moral religiosa que imperaba sobre toda conducta humana fue puesta en entredicho y abrió la posibilidad, en bien de la gobernabilidad, de disponer sobre "dos morales": la del pueblo y la del gobernante. A tareas distintas, normas distintas; y si la tarea principal en una sociedad es su gobierno, entonces el príncipe se debe ajustar a las reglas que garanticen el control de los gobernados. Cuando gobernar a través del miedo y la fuerza asegure el control del poder sobre los gobernados, pues bienvenido el Leviatán.

Para los pensadores de la antigüedad griega y medieval, la moral era condición de posibilidad de la convivencia, realización y felicidad humana. Maquiavelo representa el mentís a este axioma del pasado: en un sentido puramente manierista, asienta la pertinencia moral para cada acción de los súbditos, pero no para el gobernante. Éste se debe guiar por la "razón de Estado": lo mejor no es el bien moral, sino lo que pragmáticamente asegure el poder.

\section{La revolución económica}

Max Weber analiza la desaparición de la esclavitud en la Edad Media y concluye que esto se debió a las invasiones bárbaras y la destrucción de los

6 Sobre el "mecanicismo" en la ciencia moderna, véase Schluchter, Wolfgang, Die Entzauberung der Welt, Tübingen, Mohr Siebek Verlag, 2009. 
centros urbanos y su forma de producción. La fragmentación de las comunidades obligaría a una interdependencia de los príncipes y sus súbditos, lo que daría origen al régimen feudal medieval e imposibilitaría el sometimiento absoluto al rey, propio de la esclavitud.

El restablecimiento de un sistema económico más complejo supondría tanto el aumento poblacional y nacimiento de las urbes, como el comercio a gran escala. ¿Cómo sería esto posible sin la pacificación de las tribus vikingas (últimas en asolar Europa en el siglo IX) y la paulatina reconquista del mar mediterráneo en posesión de los sarracenos?

En los siglos XV y XVI, el mercantilismo económico trajo consigo el derrumbe del corporativismo y los gremios (que antaño posibilitaban la educación, producción y comercialización de los bienes de consumo), impuso la racionalización de los procesos de producción (como planificación y contabilidad), provocó la migración del campo a la ciudad, la aparición de condiciones inhumanas de vida (pobreza extrema), sueldos bajos, desempleo, aumento de los precios y bancarrota de las empresas. Todo esto delineaba un perfil borroso o insipiente de lo que más tarde (siglo XIX) se llamaría "capitalismo", y que marcaría el fin del feudalismo y daría lugar a una nueva era.

\section{La revolución axiológica del manierismo}

Imposible que estos cambios dejaran incólume a la sociedad y sus valores. El elemento transformador por excelencia fue la duda. Durante toda la Edad Media no hubo lugar para los escépticos, porque la verdad era Dios y se había revelado para conocimiento de los hombres, y de la misma forma que para Aristóteles, también para la sabiduría cristiana el conocimiento traía aparejado una actitud moral íntegra, y el conocimiento del logos o palabra divina era indispensable para la redención de los pecados. Por ello, poner en duda el conocimiento significaba poner en duda la moral.

En toda la Edad Media, la verdad apodíctica cristiana desterró a la duda escéptica. Sin embargo, con el desmoronamiento de la visión medieval del mundo, la revolución axiológica no se haría esperar y encarnaría en forma de duda de todo lo anteriormente aceptado y conocido. A esta revolución de los valores se le conoce como manierismo, y su principal representante fue Michel de Montaigne, porque introdujo con sus Ensayos el escepticismo pirrónico de Sexto Empírico. 
Es interesante ver cómo el manierismo, un movimiento artístico, patrocinó el escepticismo. Si bien el concepto surgió en el arte para calificar la emulación de los grandes maestros, con el tiempo refirió a la personalidad artística de cada "imitador". Desde Tiziano al Greco, la repetición de temas y técnicas derivó en la expresión caprichosa, exagerada o distorsionada de perspectivas, proporciones y posturas.

De esta forma, el manierismo ("pintar a la manera de...") se alejó del modelo que le diera vida y unidad, rompiendo el paradigma e incurriendo en un relativismo de perspectivas y valores. ¿Qué es la belleza, la proporción aurea o idónea? ¡Ninguna! y habrá tantas concepciones válidas como artistas; por ello, no es de asombrar que irrumpan en el seno del arte creaciones escatológicas, eróticas o incluso pornográficas (como el Decamerón, los Cuentos de Canterbury o, más tarde, Gargantúa y Pantagruel) con igual derecho de ser consideradas "artísticas".

La acumulación de cambios y transformaciones en los distintos ámbitos prepararon el advenimiento de un movimiento religioso de reformación como nunca antes se había visto en Occidente.

Si bien, desde el principio de su existencia, la Iglesia cristiana tuvo dificultades con sus detractores (tiempo de los apologetas), acrecentó sus disensiones frente a otras posturas e interpretaciones en la medida en que definió su doctrina (gracias a los concilios, padres y después los doctores de la Iglesia).

Martín Lutero no dijo nada para reformar la moral de la Iglesia que no estuviera ya contenido en la reforma de Gregorio Magno (en el siglo VI) o Gregorio VII (en el siglo XI) o en el espíritu de los franciscanos (en el siglo XIII). Su éxito deriva de un sistema complejo de factores, donde es difícil destacar uno por encima de otro.

\section{REFORMA Y CONTRARREFORMA}

La repercusión en nuestros días de la Reforma protestante (iniciada hace 500 años, al momento de adherir Lutero las 95 tesis en la puerta del templo de Wittenberg) se puede analizar de dos maneras: como la relevancia de las discusiones teológicas en tiempos posmodernos (y de posverdad) o como la importancia de temas como el de la tolerancia y libertad de conciencia.

Ciertamente, las 95 tesis luteranas contenían dos elementos principales: una crítica a la corrupción eclesiástica y otra a la concepción teológica. ¿Cómo desde allí se barbechó el terreno para la discusión de temas actuales 
como la tolerancia o la libertad y derecho a la objeción de conciencia? Esto acusa un tránsito de una discusión teológica a otra filosófica, y muestra el camino andado de la sociedad confesional a la sociedad civil o laica. Algo así como en la antigüedad helena fue el paso del "mito al logos", de la mentalidad imaginativa a otra puramente racional y científica. ${ }^{7}$

\section{El nacimiento de la conciencia individual}

Por un lado, es sabido que desde el papa Julián II comenzó (en 1505) la construcción de la nueva Basílica de San Pedro y que su elevado costo se sufragó en parte con la venta de indulgencias plenarias. La construcción duró más de siglo y medio con la misma estrategia de financiamiento. Cuando en 1510 viaja a Roma el joven Lutero, encuentra al papa León X y la curia romana empeñados en allegarse fondos a toda costa para costear un proyecto más ambicioso, de acuerdo con la estética renacentista. Esto motivo la ira del monje agustino y la redacción de las 95 tesis adheridas a la puerta del templo de Wittenberg.

Las indulgencias ponían sobre la mesa el tema de la culpa, arrepentimiento y perdón de los pecados. Un tema predominantemente teológico, al que se le unían otros relacionados, como el efecto salvífico de las buenas obras y la gracia divina concedida a los hombres a través de Cristo.

Como monje agustino, Lutero era un deudor del pensamiento de san Agustín, quien al respecto había creado la doctrina del pecado original, $y$, en disputa con el monje irlandés Pelagio, había sentado la concurrencia indispensable de la gracia para la salvación, en detrimento incluso de las buenas obras. ${ }^{8}$ Sólo tiene fe quien recibe la gracia, y si se cuenta con ésta, entonces se halla ya en el camino del perdón y salvación. ¿Para qué conservar una burocracia que administre el perdón si con el sacramento del bautismo y auténtica penitencia se adquiere la gracia salvífica? Además, si todo feligrés tiene la obligación de dar testimonio de Jesucristo con palabra y obra, entonces, el sacerdocio es de facto universal y no exclusivo de una élite de creyentes. Con esto, tanto el perdón de los pecados, obtenido a través de la confesión, como el sacerdote que lo dispensa, quedaban para

7 Sobre el tema del mito y el logos, véase Netsle, Wilhelm, Vom Mythos zum Logos. Die Selbstentfaltung des griechischen Denkens von Homer bis auf die Sophistik und Sokrates, Leipzig, Kröner Verlag, 1940.

8 Sobre las buenas obras y la gracia en san Agustín, véase Ratzinger, Joseph, Volk und Haus Gottes in Augustins Lehre von der Kirche, Freiburg, Herder, 2001. 
Lutero sin pertinencia y podían ser suprimidos (por ejemplo, sacramento del sacerdocio y de la confesión).

Lutero solamente dejó en pie dos sacramentos, bautismo y comunión (como consubstanciación), ¿qué había de reprochable en los otros tres restantes: confirmación, matrimonio y unción de los enfermos? Sacramento (sacramentum) es la traducción latina de la palabra misterio ( $\mu \nu \sigma \tau \varepsilon \rho ı v /$ mysterion), que significa "secreto" u "oculto". Lo que se oculta al neófito es el efecto salvífico del nacimiento, pasión y muerte de Jesucristo, sólo evidente para los hombres de buena voluntad (seres "agraciados"). De esta forma, los sacramentos habían sido instituidos por Cristo, encomendados a los apóstoles y practicados por la "Iglesia primitiva", como signos tangibles de su voluntad de salvar a la humanidad.

Los sacramentos eran siete para así arbitrar la vida entera: abarcaban desde el nacimiento hasta la muerte, pasando por las principales etapas de la vida de un feligrés, como la mayoría de edad (confirmación), el matrimonio (o sacerdocio) y escrutinio permanente de sus actos cotidianos a través de la confesión. ${ }^{9}$ A lo largo de la patrística y la escolástica, se teorizó sobre los sacramentos, gracias a lo cual san Agustín desarrolló toda una teoría del signo: el signo sacramental tiene para él un elemento material y otro inmaterial, asociado a la anamnesis de la palabra de Cristo, misma que le confiere su efectividad.

Cabe recordar que la discusión sobre la virtud de los sacramentos había sido tema reñido desde, por lo menos, el siglo IV, sobre todo por las críticas del obispo Donato a los ministros religiosos sospechosos de traicionar la fe (en tiempos de la persecución de Diocleciano). Para el donatismo, solamente quien tuviera una vida recta podría administrar los sacramentos. Lutero retoma esta cuestión disputada y la pone nuevamente sobre la mesa, evocando el añejo tema sobre la probidad de los ministros de la Iglesia y la efectividad de los sacramentos. Nuevamente, remitiéndose al padre fundador de su orden (y su doctrina sobre la gracia divina), Lutero zanja el problema con la concepción agustina de la gracia y la relevancia de las enseñanzas de Jesucristo. Para san Agustín, el hombre no puede conocer a Dios; por ello, precisa de la gracia y del ejemplo de Cristo, presente en las escrituras, para encaminarse a la salvación. De aquí la relevancia de la conciencia agraciada para creer en Dios y de la Biblia para disponer de un ejemplo de vida proba a seguir. Aparte de esto, Lutero dejó el sacramento

9 Sobre la teoría de los sacramentos, véase Müller, Gerhard Ludwig, Katholische Dogmatik, Freiburg, Herder, 1995. 
del bautismo como punto de iniciación del vínculo con Dios y la comunión como ratificación o confirmación del mismo.

\section{Contrarreforma}

El concilio de Trento, convocado en 1545, para contrarrestar el frenesí reformador, condenó esta postura de Lutero, como antaño el concilio de Arles a Donato. Sin embargo, el destino de las ideas luteranas fue muy distinto a las donatistas.

Primero, de manera sucinta, se puede decir que Martín Lutero defendió la autoridad única de las escrituras (contra la autoridad del papa) y, segundo, la autonomía de la conciencia individual para interpretarlas. Por ello, Lutero fue excomulgado en 1521, dando lugar con esto al cisma de la Iglesia.

La consecuencia inmediata en los años subsecuentes fue una ola expansiva de movimientos reformadores a lo largo y ancho de Europa occidental; por lo menos, hubo dos motivos de esta onda expansiva: por un lado, el de la gente devota que repudiaba la corrupción del clero, y por otro, las ambiciones políticas y económicas de ciertos príncipes y clérigos que añoraban para sí el poder y dinero de la Iglesia de Roma.

Siguiendo el primer motivo, se observa que muchos de los subsecuentes movimientos sectarios fueron aún más radicales que el luterano, porque proponían una reforma más profunda, como la de Jan van Leiden (15091536), uno de los fundadores del movimiento anabaptista, y que practicaba un pacifismo y pobreza extremas; Menno Simons (1496-1561), fundador de los menonitas y defensor de una vida sencilla a imagen y semejanza de la "Iglesia primitiva", y que por ello, rechazaba las "novedades tecnológicas"; Ulrico Zwinglio (1484-1531), alemán y fundador de la Iglesia reformada suiza, quien eliminó la liturgia cristiana y con ello el arte sacro; Juan Calvino (1509-1564), fundador de la Iglesia puritana y responsable del rechazo a la música, alcohol, baile y diversión, así como defensor de una sociedad teocrática; por último, el rey Tudor Enrique VIII de Inglaterra (1491-1547) fundador de la Iglesia anglicana.

La fragmentación y dureza de las posturas de las nuevas Iglesias tuvieron como consecuencias el endurecimiento de las costumbres y una persecución religiosa que derivó, más tarde, en la guerra de los 30 años (1618-1648). Esto obligó en 1555 a Carlos V de Alemania y I de España (1500-1558) a emitir un documento conocido como la "Paz de Augsburgo". Allí se preten- 
día dirimir los conflictos entre las Iglesias (así como detener su multiplicación) con las siguientes medidas:

a) El príncipe elige la religión del súbdito.

b) Los protestantes retienen las propiedades de los católicos, siempre y cuando hayan sido obtenidas antes de 1522.

c) Después de 1522 , todo aquel que se convirtiera al protestantismo no reclamará sus propiedades a la Iglesia católica.

d) No habrá otra forma de protestantismo más que el luteranismo.

e) Los luteranos (y/o católicos) no serán obligados a cambiar de religión (contra la persecución religiosa).

Ninguno de estos cinco puntos tuvo efecto alguno y comenzó la intolerancia y persecución religiosa. Entre las posturas más estrechas e intolerantes estaba la del jurista Juan Calvino (1509-1564), ${ }^{10}$ quien impuso una racionalidad jurídica y la creación de un cuerpo doctrinario sistemático. Además de aceptar - con Lutero - sólo dos sacramentos (bautismo y eucaristía) y de rechazar la liturgia católica (para dejar la lectura de la Biblia), impuso la creencia agustina en la predestinación del hombre, lo que fundó el espíritu capitalista sobre la ética protestante.

La Iglesia de Roma no permaneció con los brazos cruzados y en 1545 convocó a un concilio en Trento para organizar la Contrarreforma, con lo que se pretendía contrarrestar los efectos de la Reforma a través de renovar moralmente la Iglesia católica, defendiendo todos los dogmas (siete sacramentos), corrigiendo la traducción de la vulgata, creando el catecismo y el índice de los libros prohibidos, así como la orden de los jesuitas por parte del exmilitar español Ignacio de Loyola (en 1534), quien trabajó bajo el lema "educar para combatir la Reforma".

Descontando que el papa perdió la hegemonía y poder sobre todos los feligreses, las consecuencias (algunas) de la Reforma protestante son la incitación a la intolerancia religiosa e inicio de las purgas puritanas (como el de las "brujas"), producto del endurecimiento de costumbres y una especie de competencia sobre quiénes son mejores: protestantes o católicos. También despertó la atención sobre la educación, para alfabetizar a los feligreses y permitirles la lectura de la Biblia y/o catecismo, pero también para facilitar el distingo de una y otra secta o Iglesia. Por otro lado, estimuló

10 Sobre el reformador Juan Calvino, véase Rohloff, Reiner, Johannes Calvin: Leben, Werk, Wirkung, Stuttgart, UTB, 2011. 
la preeminencia de la fe y conciencia individual, valorando la acción del individuo y la independencia de su conciencia. Curiosamente, promovió a contrapelo la secularización de la sociedad, porque en toda región se hacía necesario un "gobierno neutral" frente a las múltiples confesiones o Iglesias. ${ }^{11}$ De la misma forma, en tiempos del absolutismo político y antiguo régimen, la Reforma sembró la semilla de la democracia, al rechazar la jerarquía eclesiástica y promover la organización horizontal de las comunidades religiosas. Por último, puede mencionarse que el cisma de la Iglesia dejó sin efecto el derecho canónico dentro de las comunidades y regiones protestantes, lo que aceleró el desarrollo del derecho civil.

\section{El hUMANISMO JURÍDICO DE LUIS DE Molina}

Éste es el horizonte histórico dentro del que se gestó el pensamiento de la Escuela de Salamanca, y que parió a su interior dos reacciones distintas: la de los dominicos, que echaron mano de las ideas aristotélico-tomistas, y la de los jesuitas, que se guiaron por san Agustín, Duns Escoto o incluso el nominalismo de Occam. En ambos casos se trataba, entre otras cosas, de justificar la evangelización de los indígenas del Nuevo Mundo apelando a su voluntad libre (y racionalidad). Para ello tenían que distinguir entre la disposición libre de los paganos con alguna o ninguna noticia de Cristo; por ejemplo, entre indígenas, judíos y sarracenos, entre la posibilidad de respetar su adhesión o rechazo al mensaje evangélico (o coaccionarlos) si habitaban o no dentro o fuera de los límites de los reinos cristianos; y, a partir de la Reforma protestante, distinguir entre los dóciles y rebeldes a la autoridad del papa, o sea, distinguir entre la voluntad que libremente acata la autoridad y aquella que sólo cree en la libertad como autodeterminación.

Luis de Molina, como miembro de la Compañía de Jesús, estaba abocado a combatir la Reforma protestante, y desde esa encomienda pretendía distinguir los distintos tipos de voluntad libre, para así explicar el derecho de aquellos que, sin tener noticia del Dios verdadero, se resistían o entregaban a los misioneros activos en América.

Sin lugar a duda, el punto de referencia más importante en la obra de Luis de Molina son los escritos de san Agustín; la razón de ello es de carácter tanto histórico como metodológico. Históricamente, san Agustín fue el pensador más importante para todo el medioevo; y en tiempos de la Re-

11 Sobre los orígenes del Estado laico, véase Zippelius, Reinhold, Staat und Kirche. Eine Geschichte von der Antike bis zur Gegenwart, München, C. H. Beck Verlag, 1997. 
forma lo demandaban para sí tanto protestantes como católicos, cada cual apelando al derecho de poseer la más fiel de las interpretaciones de su pensamiento. Desde el punto metodológico, la concepción de san Agustín sobre la voluntad permitía solucionar los problemas de la elección del bien y del mal. En el primer caso, el problema de la elección correcta, o aceptación de la fe en Dios, representaba una perplejidad debido a que, si Dios es incomprensible para el hombre, cómo puede éste elegir aquello que no conoce o no entiende; $;^{12}$ y en el segundo caso, desconcertaba saber que, si la elección del bien beneficia al hombre, por qué entonces elige el mal. ${ }^{13}$

Esta elección consciente del mal moral no era explicable para los filósofos de la Antigüedad: Platón ${ }^{14}$ declara el problema como inexplicable o, en el mejor de los casos, producto de la ignorancia; Aristóteles, en el libro VII de la Ética nicomáquea, reconoce su posibilidad bajo el título de acracia, ${ }^{15}$ pero sin solucionar el problema de manera satisfactoria. En cambio, dentro de la doctrina agustina sí es posible aclarar estos problemas porque la voluntad constituye una facultad independiente de la razón o afectos. Antes bien, la voluntad antecede tanto al conocimiento del ser como a su subsecuente hacer sin que precise el concurso de la razón. Lo que implica para san Agustín, que la fe no sea forzosamente el resultado de un acto racional y que la elección de Dios constriña a algún conocimiento previo. ${ }^{16} \mathrm{La}$ vo-

12 San Agustín, De la Santísima Trinidad, lib. VIII, c. IV, núm. 6, Madrid, BAC, 1968. Allí se pregunta san Agustín: "Mas ¿quién ama lo que ignora? Se puede conocer una cosa y no amarla; pero pregunto: ¿es posible amar lo que se desconoce? Y si esto no es posible, nadie ama a Dios antes de conocerlo. Y ¿qué es conocer a Dios, sino contemplarle y percibirle con toda firmeza?".

13 San Agustín, “Todos desean ser felices, ¿por qué tan pocos lo consiguen?”, El libre arbitrio, lib. I, núm. 100, Madrid, BAC, 1968. Allí se pregunta san Agustín: “¿Cómo explicar que los que viven una vida miserable lo hagan por su propia voluntad, siendo así que nadie quiere vivir miserablemente?".

14 Platón, Protágoras, 356 c/357 e, y 358 a/360 e. Allí dice Platón: “Qué otra conclusión sacar de ello, sino que nadie tiende por propio gusto y voluntad hacia lo que es malo o lo que él cree malo, que incluso parece contrario a la naturaleza del hombre buscar lo que se cree malo con preferencia de lo bueno, y finalmente que, si es inevitablemente preciso escoger entre dos males, nadie va a preferir el mayor cuando le sea posible quedarse con el menor".

15 "Acracia" (o incontinencia o debilidad de la voluntad) refiere a la situación en que el agente, a pesar de considerar con claridad que cierto curso de acción es el mejor, falla en obrar conforme a esta consideración. Véase Aristóteles, Ética nicomáquea, lib. VII, cs. II y VIII, México, UNAM, 1983, pp. 154 y ss. y pp. 168 y ss., respectivamente.

16 San Agustín, De la Santísima Trinidad, lib. VIII, c. IV, núm. 6, Madrid, BAC, 1968. Siguiendo a san Agustín, Molina afirma en la Disputa II, p. 51: "Ahora bien, Dios permanece totalmente oculto a nosotros, mientras vivimos en la prisión tenebrosa del cuerpo". Molina, 
luntad constituye una facultad a la base de cada acción, sólo inseparable de la razón cuando se trataba del ejercicio del libre arbitrio. La voluntad es la fuente de la acción moral simplemente porque es la fuente de toda acción humana posible, ${ }^{17}$ y porque no está determinada previamente por nada, lo que le permite elegir siempre entre hacer o de dejar de hacer o elegir en contra de sí misma, por ejemplo, elegir el mal.

Gracias a que san Agustín concibe la voluntad como facultad autónoma, con capacidad de determinarse a sí misma sin ayuda de la razón (o alguna otra facultad distinta), es por qué se explica el absurdo de la elección del mal. En este sentido se contrapone a Aristóteles, quien entendía la voluntad como una acompañante inseparable de la razón para llevar a cabo acciones deliberadas. Con san Agustín, la voluntad será simplemente una facultad de elección entre dos alternativas, sin importar su correspondencia o no con la razón y el bien. ${ }^{18}$

No hay que relegar a segundo plano la razón histórica para que Molina se remita al obispo de Hipona, porque al lado de la indiscutible relevancia doctrinal de sus ideas sobre la gracia y la voluntad, los acontecimientos de la Reforma protestante demandaban la atención del jesuita: de la misma manera en que Molina reclamaba para sí las ideas de san Agustín, así también lo hizo su enemigo Martín Lutero. ${ }^{19}$ Molina pretendía refutar las desvergonzadas interpretaciones de Lutero y con ello desechar el supuesto derecho de los protestantes a fundar en él sus ideas. ${ }^{20}$

Luis de, Concordia del libre arbitrio con los dones de la gracia y con la presciencia, providencia, predestinación y reprobación divinas, Oviedo, Pentalfa ediciones, 2007.

17 Por ejemplo, haciendo a un lado en este momento los actos involuntarios y contravoluntarios.

18 Para profundizar en san Agustín sus ideas sobre la operación de la voluntad y su influencia en Descartes, véase Hindrichs, Gunnar, Das Absolute und das Subjekt, Frankfurt am Main, V. Klostermann, 2008, pp. 227 y ss.

19 Lutero, M., Operationes in Salmos, ps. 5, Berlín, Vadenhoeck \& Ruprecht, 2002, t. 5, p. 177.

20 Dice Molina, en la Disputa I, núm. 20: “20. Calvino persiste en el error de Lutero y reconoce que los filósofos, así como los Padres de la Iglesia, enseñan lo contrario. Pero afirma que los Padres lo hicieron con la siguiente intención, a saber, para no inducir a risa a los filósofos, pretendiendo enseñar lo contrario de una opinión tan extendida entre ellos. Ahora bien, ¿quién no ve que algo así sólo se puede decir de manera frívola y estúpida? No obstante, sólo exceptuó a san Agustín, a quien presenta, de manera desvergonzada y falsa, como patrono de su error". Molina, Luis de, op. cit. 


\section{El concepto de acto voluntario de Luis de Molina}

El concepto de voluntad utilizado por Molina es en su médula agustino; ${ }^{21}$ sin embargo, acusa otros elementos que conducen a dos conceptos de libertad en apariencia armónicos: uno agustino y otro descrito en términos aristotélicos. La razón de ello se explica, en parte, por el espíritu conciliador del fundador y maestro Francisco Vitoria; pero, por otra parte, se explica por el deseo de Molina de contar con un concepto de voluntad opuesta a la doctrina de los reformadores (ante todo Lutero), donde la voluntad humana en estado de pecado pueda ser llamada libre, y por ello, tener en su poder el cometer obras buenas.

La teoría de Molina sobre la libertad de la voluntad se encuentra en su texto sobre la Concordia, ${ }^{22}$ cuya parte principal está dedicada a dilucidar el concepto de libertad y elección libre. A continuación, se expondrá a Aristóteles y san Agustín, para finalizar con Luis de Molina.

\section{El concepto aristotélico de acto voluntario}

Aristóteles desarrolla su concepto de "acto voluntario" (que no debe ser confundido con su teoría completa sobre la libertad de elección) al principio del libro III de la Ética nicomáquea. ${ }^{23}$ Su motivo puede ser formulado así: ¿cómo están constituidos los comportamientos humanos que merecen ser elogiados o vituperados?; con otras palabras: ¿cuáles actos son responsabilidad del sujeto? ${ }^{24}$

La buscada condición de responsabilidad para culpar o recompensar es — siguiendo a Aristóteles - la voluntad (que el acto sea voluntario). En oposición están los actos contravoluntarios e involuntarios que son aquellos realizados por coacción o por ignorancia, respectivamente. ${ }^{25}$ En el caso de los actos productos de la coacción, el agente no es origen del movimiento o acción - según Aristóteles-. El criterio que caracteriza al acto involuntario de manera negativa es la ignorancia. ${ }^{26}$ Ésta no se presenta únicamente

21 Molina dice en su Disputa II: "Por lo demás, considero que la libertad se halla en la voluntad y no en el entendimiento". Idem.

22 Idem.

23 Aristóteles, op. cit., pp. 154 y ss., pp. 168 y ss.

24 Idem.

25 Sobre Aristóteles y los actos in y contravoluntarios, véase idem.

26

Idem. 
respecto de las reglas de la moral sino también de las condiciones o circunstancias de cada acción que, por su carácter propio, excluye conocimiento certero y completo, provocando equivocaciones. Exceptuando la conciencia del mismo agente (respecto de su yo y su intencionalidad), puede haber ignorancia en relación con cada uno de los factores de cada acción particular, si bien no de todos los factores al mismo tiempo; esto es: la ignorancia puede estar relacionada con las condiciones propias en las que se realiza la acción, con las personas o cosas involucradas, con el tipo mismo de acción, o sea con los medios para su realización, con la duración de la misma y su relación al fin. Si la ignorancia de uno de esos factores conduce a la realización de una acción, que después de cometida se lamenta, entonces puede ser caracterizada de involuntaria. Por el contrario, un acto voluntario tiene lugar cuando el origen del acto se encuentra en el agente (intencionalidad del agente), y éste conoce los detalles circunstanciales más relevantes del acto en cuestión y, por tanto, no lamenta el acto. ${ }^{27}$

Aquí no se trata de discutir si dentro de la teoría de Aristóteles, enfocada al análisis de casos concretos, puede haber actos voluntarios en pleno sentido del término (o sea, donde sólo la intención del agente sea relevante para llevar a cabo la acción). Antes bien, hay que preguntarse con Aristóteles, cómo es posible la adjudicación de responsabilidad moral por los actos realizados; porque el acto voluntario es común tanto a niños como a animales (intencionalidad), si bien ninguno dispone de capacidad de deliberación racional y, por lo mismo, no sea posible adjudicarles responsabilidad moral. Esto muestra que tanto la capacidad de decisión como la deliberación racional son para Aristóteles condición suficiente para adjudicar responsabilidad moral. $^{28}$

Con ello es de atender que el concepto aristotélico de "capacidad de decisión y deliberación racional" no designa la capacidad de elegir entre distintas alternativas, sino un proceso de evaluación de la mejor de las alternativas. De forma tal que, en cada caso particular, la mayoría de las opciones a elegir quedan excluidas y sólo una (por ejemplo, la mejor) se presenta a elección. La voluntad entendida como "capacidad de decisión y deliberación racional" denota el resultado de un proceso a lo largo del cual se averigua la mejor posibilidad a elección, independientemente del deseo y de las muchas o pocas posibilidades reales de elección. Correspondiendo a esto, el resultado de la capacidad de decisión, vía valoración racional,

\footnotetext{
27 Idem.

28 Idem.
} 
funciona también como causa eficiente de la acción, sin precisar de ningún otro factor. ${ }^{29}$

En conclusión, la capacidad de decisión y deliberación racional se refiere a un proceso de valoración racional de la mejor opción. Por eso mismo se entiende la capacidad de decisión como la conclusión de una deliberación racional que no permite ninguna alternativa distinta. Lo que dota a la capacidad de decisión de una estructura lógica, expresada en la figura de un silogismo práctico, ${ }^{30}$ que permite hablar de un acto voluntario como aquel que está precedido de una ponderación racional de las alternativas dispuesta a elección, en donde el agente está libre de toda coacción y cuenta con conocimiento o información suficiente sobre las condiciones concretas de su realización.

En un silogismo práctico, la premisa menor estará planteada correctamente si se atiene racionalmente al fin que persigue la premisa mayor, y sólo cabrá la posibilidad de enunciar erróneamente la premisa mayor cuando se trate de una persona con "carácter enfermo". ${ }^{31}$ Con esto se muestra que el concepto de acto voluntario de Aristóteles implica un proceso de elección puramente racional que excluye el sentido de elegir dentro de un abanico de múltiples alternativas.

\section{Concepto agustino de acto voluntario}

En la teoría agustina de la libertad de voluntad no hay una conexión necesaria entre el análisis racional de la mejor opción a elegir y la capacidad humana de decisión que finalmente elige y realiza la acción, porque san Agustín afirma que, de ser así, la razón volvería superfluo el acto de la voluntad. ${ }^{32}$ Por eso, san Agustín agrega al concepto aristotélico de libertad ${ }^{33}$ una nueva dimensión, distinta a aquella que se presenta en la relación causal entre decisión racional y realización del acto, que se puede caracterizar de manera positiva como libertad de elección entre dos alternativas, a saber: entre hacer o dejar de hacer.

29 Incluyendo en principio la posibilidad real de elección, si bien "la posibilidad real de acción" forma parte de la "mejor elección" por ser aquella que puede ser realizada.

30 Sobre Aristóteles y el silogismo práctico, véase los Primeros analíticos.

31 Acracia, o como más tarde se le nombrara en la Edad Media, "acedia", es considerada como una enfermedad.

32 Véase san Agustín, De libero arbitrio, lib. I, Madrid, BAC, 1968.

33 San Agustín no tuvo conocimiento directo de la obra de Aristóteles, como tampoco de Platón. 
Aquí no es el lugar para considerar una tercera dimensión de la libertad, entendida como "libertad absoluta" o posibilidad de elegir entre toda posible acción (sin tomar en cuenta la influencia del ambiente exterior al agente), que - para san Agustín - sería el caso del hombre antes del pecado original. Las dos primeras dimensiones de la libertad (por ejemplo, racionalidad y elección entre más de una alternativa) bastan para exponer la doctrina de san Agustín sobre la libertad y responsabilidad del hombre.

A continuación, se tomarán en cuenta las ideas de san Agustín vertidas sobre todo en su obra sobre el libre arbitrio (De libero arbitrio), escrita entre 388-395. Esto por dos razones: primero, porque el mismo san Agustín permaneció fiel a esas ideas, pese a las modificaciones y retractaciones posteriores; $\mathrm{y}$, segundo, porque los filósofos de la escolástica tardía (como Molina) prestaron poca atención al desarrollo posterior de la doctrina de san Agustín y aceptaron principalmente sus ideas expuestas en De libero arbitrio.

\section{La voluntad}

Primero, para san Agustín es evidente que existe la voluntad desde el momento que expresamos un deseo. El ejemplo que ofrece san Agustín es "el deseo de saber" expresado por su interlocutor del diálogo, quien le formula la pregunta: “¿Existe la voluntad?”; la respuesta es inmediata, porque está implícita en la expresión misma del deseo (por ejemplo, toda pregunta expresa un deseo de saber; y esto supone la existencia de una voluntad de saber). Segundo, como pertenece a la constitución del hombre el tener tanto razón como voluntad, y como el hombre es una creatura divina, es la voluntad un bien, simplemente porque todo lo que ha creado Dios es bueno. Ciertamente no es la voluntad un bien de la misma manera como lo es la razón o la virtud, porque de estas dos últimas no se puede hacer un uso indebido, mientras que de la voluntad sí puede el hombre hacer un uso indebido, ya que Dios no puede obligarla al bien sin destruirla. Sin embargo, la voluntad ha sido dada al hombre para llevar una vida justa, es decir, para que éste haga de ella un uso correcto, por ejemplo, según la razón y virtud (en este caso se llama libre arbitrio). Tercero, san Agustín concibe la voluntad como aquella capacidad del alma que puede elegir o rechazar, hacer o dejar de hacer. La representación de las cosas a elegir o rechazar es operación exclusiva de la facultad de conocimiento, que a su vez depende de la facultad de percepción y representación. Como no está en la facultad de la 
voluntad controlar las sensaciones y representaciones, no se le puede hacer responsable de ellas. Lo que sí está dentro de su facultad, y responsabilidad, es el convertir dichas representaciones en objeto de sus deseos y acciones. La esencia de la voluntad consiste en ser libre o autodeterminarse, porque —opina san Agustín - "sería contradictorio e inimaginable" que "estar en nuestra fuerza" significara otra cosa a "poder hacer lo que deseamos". Es más; no hay otra cosa que esté bajo nuestro poder que la voluntad misma. Tan pronto como nosotros deseamos algo, interviene inmediatamente la voluntad. En consecuencia, no hay ninguna otra explicación de nuestros deseos si no la voluntad, porque de lo contrario la voluntad dejaría de ser lo que es. ${ }^{34}$

\section{La voluntad corrompida}

En este punto de su desarrollo, la teoría de san Agustín sobre la libertad de la voluntad se encuentra bajo sospecha de herejía y coincidiendo con la tesis defendida por el monje herético Pelagio, ${ }^{35}$ a saber: que la constitución racional y libre del hombre es suficiente para que, sin ayuda de la gracia divina, entienda el mensaje de Dios, obedezca sus mandamientos y, de esa manera, devenga santo con su sólo esfuerzo.

Esto representaba una interpretación equivocada de la voluntad humana, en contra de la cual el mismo san Agustín se defendió en su escrito contra Pelagio De natura et gratia, así como, en su escrito aclaratorio Retractationes, ya que el mismo Pelagio utilizó en la elaboración de sus ideas el libro de san Agustín De libero arbitrio. San Agustín criticó al pelagianismo por no dar lugar alguno a la gracia divina, porque si bien la voluntad es aquello que el hombre precisa para vivir justamente (o pecaminosamente):

no pueden los mortales vivir justa y piadosamente si la voluntad no ha sido liberada por la gracia divina de la servidumbre del pecado en la que el hom-

\footnotetext{
34 San Agustín, De libero..., cit.

35 Pelagio, monje irlandés contemporáneo de san Agustín (354-430), negó la doctrina del pecado original y la necesidad de la gracia divina para alcanzar la salvación, porque ello implicaba para él la negación del libre arbitrio. Molina cita a Pelagio en Disputa I. Sobre los errores acerca de la presciencia divina, nuestro libre arbitrio y la contingencia de las cosas: "12. El error de los pelagianos surgió en tiempos de san Agustín, después de que éste escribiera los libros de su De libero arbitrio y muchas otras obras insignes, como él mismo atestigua en sus Retractationes (lib. 1, cap. 931). Este error se oponía a la verdad y a la fe, y era totalmente contrario al de los maniqueos. Pues Pelagio y sus seguidores ensalzaban más de lo justo las fuerzas del libre arbitrio, en perjuicio de la gracia necesaria para nuestra salvación”. Molina, Luis, op. cit.
} 
bre ha caído. Sólo por la gracia de Dios superará el hombre sus errores, y si el regalo liberador de Dios no antecede a la voluntad, no sería éste una 'gracia' sino un objeto del deseo o una recompensa a sus merecimientos. Es una gracia, porque ha sido dada de manera gratuita e incondicionada [antes de hacer cualquier cosa para merecerla $(\mathrm{N}$. del A.) $] .^{36}$

No es necesario analizar en detalle la doctrina de san Agustín sobre el pecado original y la gracia divina, desarrollada poco después de haber escrito De libero arbitrio; es suficiente bosquejar las consecuencias del pecado original para la voluntad humana tomando algunos pasajes de esa obra. San Agustín distingue de manera categórica, en el III del De libero arbitrio, entre el estado del hombre al momento de ser creado y su estado después de haber pecado. ${ }^{37}$ Ambos estados se distinguen por la diferente forma en que se orienta la voluntad; porque, si bien la voluntad se autodetermina antes como después del pecado, no dispone de la misma capacidad de representación del buen comportamiento para determinarse a actuar conforme a éste. Esa carencia de representación del buen comportamiento (objeto importante para que la voluntad pueda tomar una decisión) tiene su causa en la corrupción de la naturaleza humana debido al pecado original, y consiste en dos cosas:

a) En la renuncia al orden eterno y

b) En la primacía del interés por las cosas temporales (lo que no permiten el conocimiento del orden divino, porque las cosas temporales no remiten a él).

Como todo acto del libre arbitrio presupone el conocimiento de hacia dónde se dirige, y como la voluntad después del pecado original no está orientada a la eternidad, no puede ser la eternidad objeto de representación elegible; por tanto, no puede la voluntad ser el origen de actos buenos partiendo de ella misma. ${ }^{38}$

Esta corrupción de la naturaleza humana no debe ser entendida como si el hombre antes de haber pecado estuviera dispensado de sensualidad, corporeidad o sensaciones, sino antes bien como el estado donde el hombre disponía del conocimiento sobre la justa relación entre las cosas eternas y

\footnotetext{
36 San Agustín, De natura et gratia, Madrid, BAC, 1968.

37 San Agustín, De libero arbitrio, lib. I, Madrid, BAC, 1968.

38 San Agustín, sobre la importancia de la gracia para hacer el bien.
} 
temporales. De lo que se derivaba el control de la sensualidad para que estuviera en todo momento sometida a su voluntad raciona.

Debido a esto debe entenderse el discurso de san Agustín en dos formas distintas: en sentido propio, "naturaleza humana" significa aquella naturaleza sin culpa con la que fue creado el hombre por Dios. En un sentido derivado, "naturaleza humana" significa aquella sometida a la muerte, ignorancia, a un cuerpo o sensualidad. Lo que representa el castigo por haber pecado.

Esa condición natural de estar en pecado, caracterizado por la ignorancia y debilidad de los hombres, constituye una "responsabilidad sin culpa". ${ }^{39}$ Lo que quiere decir ausencia de conocimiento sobre el deber-ser del alma, deber de trascender la codicia por el mundo a que orienta su naturaleza corrompida. ${ }^{40}$ El hombre, dentro de su condición de naturaleza caída, puede comportarse conforme a la moral natural y, por tanto, indirectamente fiel a la ley de Dios. Sin embargo, todos los esfuerzos morales para alcanzar un buen comportamiento serán insuficientes para superar irreversiblemente el estado de pecado, porque la proclividad hacia lo mundano temporal, prueba de la corrupción de la voluntad, opera sin tregua ni tardanza. A partir de ello sólo se puede elegir el mal, representado por lo mundano pasajero opuesto a lo eterno permanente. El regreso de la voluntad al orden eterno es exitoso bajo la condición de liberarse de la "servidumbre del pecado", consistente en contemplar el mundo y a uno mismo como soberano o ajeno a su Dios, su creador. ${ }^{41}$

Si bien la gracia divina, cuyo principio está en la fe cedida sin condición de ser aceptada o rechazada, posibilita el éxito del alma anhelante de Dios para el conocimiento y cumplimiento de su deber, la voluntad posee, de suyo, libertad para elegir trascender el interés inmediato en la búsqueda del conocimiento eterno, para "religar" la conciencia de subordinación a Dios; lo que implica que la voluntad asuma el orden divino, ${ }^{42}$ aunque éste no le sea del todo conocido. Entonces, aun la voluntad corrompida tiene control de sí y en consecuencia es libre de elegir la "representación de lo eterno" (imposible de producir enteramente desde sí misma). Pese a que el hombre no puede desear tener fe, si puede aceptar la fe y aceptar la representación

39 San Agustín, sobre el concepto de "responsabilidad sin culpa".

40 Por ejemplo, se establece cómodamente en un orden mundano con el fin de realizar y regular la vida en comunidad.

41 Para profundizar en san Agustín y su noción de pecado, véase Pieper, Josef, Über den Begriff der Sünde, München, Verlag Kösel \& Pustet, 1977, pp. 27 y ss.

42 Ese orden divino significa para la condición humana someter lo corporal a lo racional. 
que manda vivir conforme a un orden eterno, incluso sin haberlo conocido y entendido del todo.

Lejos de creer que con este bosquejo quede completo el análisis de la tensión existente dentro de la doctrina de san Agustín entre las tesis: "la gracia es la única causa de la elección correcta de la voluntad", y su contrapartida: "la voluntad se encuentra bajo el completo control de los hombres", se puede pasar al análisis del concepto de voluntad de Luis de Molina, desarrollado en la primera parte del texto Concordia.

\section{La teoría de Luis de Molina sobre la libertad de la voluntad}

La primera parte de la Concordia lleva por título De virtutibus liberi arbitrii ad opera bona (Sobre las fuerzas del libre arbitrio para obrar el bien), allí Molina desea demostrar, contra la doctrina de los reformadores ${ }^{43}$ (ante todo contra Lutero), que la voluntad humana en estado de pecado puede ser llamada libre, y que está en su poder o capacidad hacer obras buenas.

Aquí no se puede discutir con amplitud la medida en que radicaliza Luis de Molina la doctrina de la gracia divina de san Agustín, como tampoco si entendió bien o no a Lutero; simplemente se expondrán sus ideas al respecto.

\section{Crítica de Molina a Lutero}

Con relación al tema de la libertad de la voluntad, ${ }^{44}$ Molina toma dos tesis de Lutero: primeramente, Lutero rechaza la concepción sobre la voluntad libre entendida como un "deseo interno" del individuo, a través del cual elige, por ejemplo, el bien. Para Lutero ese desear per se no tiene eficacia

43 Molina, Luis de, "Disputa I. Sobre los errores acerca de la presciencia divina, nuestro libre arbitrio y la contingencia de las cosas”, op. cit., núm. 17, p. 43. Ahí afirma Molina: "Como consta según el Concilio de Constanza (ses. 8, art. 27), en el que se condenó a Juan Wycliff, éste sostuvo que todo acontece por necesidad absoluta. Se dice $-\mathrm{y}$ también parece- que Juan Hus, condenado por este mismo Concilio (ses. 15), cayó en el mismo error. También se cree que Lorenzo Valla se adhirió a las tesis de estos herejes, como cuenta el decano lovaniense Ruardo Tapper, en su artículo sobre el libre arbitrio [...] y Lutero, pues éste, por decirlo ya, sigue la doctrina de Wycliff en este punto".

44 La expresión liberum arbitrium fue utilizada muchas veces como sinónimo de "voluntad libre". 
alguna, sino sólo cuando su "eficacia" viene de Dios ${ }^{45}$ Molina critica que de esta manera la voluntad humana se comportaría, cuando llega a desear hacer el bien, de una manera pasiva: "18. En primer lugar, Lutero afirmó que el libre arbitrio carece de eficacia en relación a las voliciones internas en virtud de las cuales quiere algún bien, porque la producción eficaz de éstas dependería únicamente de Dios y la voluntad humana permanecería pasiva cuando apetece algún bien". ${ }^{46}$

En contraposición, afirma Molina que el acto de desear algo, propio de la voluntad e intelecto, sólo puede ser llamado correctamente de esa forma si es "eficaz per se", es decir, un acto imputable a la voluntad.

Segundo, si la primera tesis de Lutero contradice tanto la recta fe, como el sentido común y la filosofía verdadera, la segunda tesis — según Molina- supera el maniqueísmo en tontería y ateísmo, porque quita al hombre el control sobre la "libre decisión" en cualquier contexto que sea. La segunda tesis fue formulada por Lutero de dos formas: una débil y otra fuerte, representando la segunda una precisión de la primera formulación; ambas fueron rechazadas por Molina ${ }^{47}$ La primera formulación dice: "Pero Lutero añadió que, no obstante, en tanto que en última instancia nuestra voluntad ordena ejecutar el acto bueno como obra externa, se dice que coopera y despliega una actividad al ejecutarlo. De ahí que Lutero enseñase que, tras caer en pecado o antes de recibir la gracia, el libre arbitrio no es sino una cosa que sólo admite una consideración nominal". ${ }^{48}$

A partir de esto enseñaba Lutero que la "decisión libre", después del pecado o antes de la gracia, sólo de nombre podía ser considerada un efecto y no un defecto. La precisión de Lutero se dio como respuesta a la condena del papa León X de 1520 con la bula Exsurge Domine. Él escribió en el Assertio omnium su tesis 36 :

Hablé mal, cuando dije que, antes de recibir la gracia, el libre arbitrio no es sino una cosa que sólo admite una consideración nominal, porque, sin más, debí decir que el libre arbitrio es una ficción que se aplica a las cosas, es decir, un nombre sin contenido, porque nadie tiene en su mano la posibilidad de tener pensamientos buenos o malos, sino que, por el contrario (como enseña el artículo de Wycliff condenado por el Concilio de Constanza), todo sucede

\footnotetext{
45 Molina, Luis de, "Disputa I...", op. cit., núm. 18 y ss.

46 Idem.

47 Molina, Luis de, "Disputa I...", op. cit.

48 Lutero citado por Molina.
} 
por necesidad absoluta, como también pensaba el poeta, cuando dijo: Todo está sujeto a una ley inmutable. ${ }^{49}$

Lo que deseaba demostrar Molina a partir de la exposición de Lutero es, primeramente, que una "decisión libre" es un efecto real y que la "capacidad de decisión" existe aún en estado de pecado. Segundo, Molina desea demostrar que la voluntad no se comporta de manera pasiva en la ejecución de buenas obras sino de manera activa, y que, debido a su poder de mando, está en condiciones de hacer buenas obras aún en estado de pecado.

\section{El concepto de Molina de voluntad libre}

¿Qué entiende Molina por libre arbitrio? Molina elucida el concepto en su segunda disputa ${ }^{50}$ de la primera parte de la Concordia.

\section{A. Conducta natural, libre y moral}

Molina comienza su análisis del concepto de libertad con la aclaración de que no se tratará simplemente de cuestiones teológicas o de historia sagrada, como sería el caso de considerar la caída del hombre en pecado y el papel de la gracia divina. Antes bien, Molina se aplica al análisis filosófico y moral del concepto, tal como queda explicitado en la expresión latina libet (por ejemplo, el deseo personal cumplido en una actividad). Él distingue, para comenzar, entre dos usos del término; el primero surge de la oposición a necesidad: todo aquello que ocurra a partir de la propia iniciativa o intención, corresponda o no con el orden natural, será entendido como libre. ${ }^{51}$ Sin embargo, un comportamiento voluntario en este sentido no es suficiente para explicar cabalmente lo que significa libre arbitrio, porque tanto niños como locos, e incluso animales, pueden realizar una actividad a partir de sí mismos (intencionalidad), pero sin la consecuente responsabilidad moral.

49 Molina, Luis de, "Disputa I...”, op. cit., núm. 18, p. 44. Lutero se refiere al Fatum en la sentencia de Marco Manilio en su obra Astrología: "fata regunt orbem, certa stant omnia lege/longaque per certos signantur tempora casus. Nascentes morimur, fi nisque ab origine pendet".

50 Molina, Luis de, "Disputa II. ¿Qué debe entenderse bajo el nombre de 'libre arbitrio'?", op. cit.

51 Ibidem, núm. 3, p. 46. Ahí dice: “3. Del segundo modo, la libertad puede considerarse como opuesta a la necesidad. Así se dice que agente libre es aquel que, puestos todos los requisitos para actuar, puede actuar y no actuar, o hacer una cosa lo mismo que la contraria". 
4. Aquí debemos señalar dos cosas. Primera: Los niños y los dementes no sólo obran por propio impulso, sino que también realizan muchos actos libremente, de tal modo que en su potestad estaría realizarlos o no o incluso hacer lo contrario, como afirmamos con el P. Francisco de Vitoria en nuestros Commentaria in primam secundae (q. 1, a. 171). Sin embargo, todos estos actos no se les pueden imputar como culposos, ni como meritorios, porque no disciernen entre el bien y el mal morales haciendo uso de razón, como se requiere para que un acto sea culposo o meritorio. Por este motivo, aunque estén en posesión de algún uso del libre arbitrio, sin embargo, carecen del que se requiere para que sus actos sean culposos o meritorios. Ese primer uso, como establecen las leyes, es aquel en posesión del cual, según se dice, los niños estarían hasta el momento de cumplir los ocho años de edad. ${ }^{52}$

Por eso, no se entiende el concepto de libertad simplemente como opuesto al de necesidad. Tener libertad de decisión implica además lo siguiente:

Por eso, ha sido tenido un comportamiento por libre cuando puede actuar o dejar de actuar — suponiendo todas las condiciones externas necesarias para la acción-. Y a partir de ese sentido se hablará de la capacidad de ser libre de un agente (sujeto). Pero si actúa de manera tal que antecede a su decisión un juicio de razón, entonces la decisión será libre gracias a que descansa en este juicio racional. Eso hace que la decisión libre no sea otra cosa que la voluntad unida a un juicio de la razón (libre arbitrio). En ambos sentidos, el agente libre será distinto del agente que actúa siguiendo el orden natural, el cual no tiene poder de actuar o no actuar sino solamente de actuar de manera necesaria. Porque actuar de manera natural es actuar de manera tal que no pudiera hacer otra cosa distinta. ${ }^{53}$

Molina afirma que la acción libre se distingue de la natural precisamente en que, para esta última, las condiciones de posibilidad de la acción constituyen la condición suficiente de la misma; de tal manera que siempre se seguirá una acción cuando ellas estén presentes. Mientras que, para la acción libre, las condiciones externas para la acción no constituyen condición suficiente alguna, sino sólo necesaria, porque para que se dé la acción se necesita, además, de la decisión voluntaria (que siempre contará con por lo menos dos alternativas a elección, si ha de ser considerada causa u origen de una acción).

\footnotetext{
52 Idem.

53 Véase Molina, Luis de, "Disputa II" de la primera parte, op cit.
} 
Si bien el juicio racional califica a la voluntad como libre, no implica por ello que la libertad de la voluntad se reduzca al ejercicio de la razón; pues en algunos casos la voluntad opera sin un juicio racional previo. Con esto, la interpretación del pensamiento de Luis de Molina (según la cual su concepto de voluntad libre no se reduce al de Aristóteles) encuentra su asidero, y abre la posibilidad a dos maneras posibles de experimentarse: una psicológica y otra moral.

La experiencia psicológica, por un lado, caracteriza a la voluntad libre sin apuntalamiento racional, lo que explica cómo niños y locos actúan voluntariamente sin ayuda de la razón y sin distinguir entre bien y mal moral (sin libre arbitrio), y por tanto, sin responsabilidad o posibilidad de premio o castigo. La experiencia moral, por otro lado, integra el juicio de la razón a la voluntad, lo que constituye la condición necesaria de los actos responsables y susceptibles de ser juzgados moralmente. Esto permite a Molina hablar tanto de la voluntad libre del hombre a lo largo de toda su vida como de la responsabilidad moral a lo largo de su vida racional. Pero también permite plantear la posibilidad de que el hombre elija haciendo uso o no de la razón, persiguiendo el bien o el mal, o absteniéndose de llevar a cabo elección alguna.

\section{B. La naturaleza de la voluntad humana}

Aquí surgen dos preguntas: ¿Por qué prevalece la libertad de la voluntad en estado de pecado (y sin el don de la gracia), cuando en este caso no existe la opción de elegir por la salvación? ¿No se colige necesariamente que la razón se halla en las dos concepciones y experiencias de libertad, psicológica y moral, con el fin de hacer posible una elección?

Molina responde distinguiendo en el modelo agustino, expuesto en su obra de Libero arbitrio, cuatro estados de la naturaleza humana, ${ }^{54}$ que por razones metodológicas son desglosados por Molina en los siguientes cinco estados: a) El estado de la naturaleza humana sin pecado ni gracia; b) El estado de la naturaleza humana en gozo de la gracia; c) El estado de la naturaleza humana en pecado, pero disponiendo de sus capacidades naturales; d) El estado de la naturaleza humana en pecado, pero disponiendo de la gracia ofrecida por Jesucristo, y e) El estado de la naturaleza humana en completa gracia.

54 Molina, Luis de, "Disputa III. Sobre el cuádruple estado de la naturaleza humana”, op. cit., núm. 2-6, pp. 52-55. 
1) El estado de la naturaleza humana sin pecado ni gracia es — según Molina - un estado ficticio que ningún hombre posee o poseerá; es simplemente imaginable o lógicamente posible..$^{55}$ Este estado, sin embargo, sirve para distinguir dos capacidades distintas: el conocimiento y el deseo. Así revela Molina, respaldado en san Agustín y su idea sobre las dos voluntades enfrentadas, que la naturaleza humana se encuentra escindida por aquello que impedirá realizar su fin natural y aquello que permitirá su fin sobrenatural, consistente en vivir según la razón y unirse a Dios.

2) En el estado de inocencia o previo al pecado, el hombre halla armonía entre sus partes sensitiva y racional, porque dispone de la justicia natural sumada a las virtudes sobrenaturales. En este estado le es posible alcanzar la visión clara de Dios y su unidad con él.

3) En el estado de pecado se ha perdido toda capacidad sobrenatural, por lo cual le es imposible al hombre promover la salvación de su alma a partir de sus propias fuerzas y merecimientos. Sin embargo, el hombre dispone aún de sus capacidades naturales (racionalidad y libertad de la voluntad), que le permiten realizar actos morales buenos (aunque insuficientes para la promoción de su salvación). La caída en pecado no ha robado al hombre la posibilidad de alcanzar su fin natural cumpliendo con la justicia natural. Sin embargo, está impedido para tener una función racional correcta y una decisión siempre certera. De este estado provendrán todas las penas del tiempo, así como la muerte.

4) El acto de salvación de Jesucristo abre al hombre de nuevo la posibilidad de alcanzar su fin sobrenatural. Este acto de salvación no traslada al hombre a su estado primigenio de inocencia, porque el hombre permanece incapaz, partiendo de su propio impulso, de promover a través de su propio merecimiento la salvación definitiva de su alma. Sin embargo, consigue nuevamente representarse su meta

55 Molina dice en op. cit., núm. 2, pp. 52 y 53: "El hombre jamás se ha encontrado en un estado tal y jamás lo hará. No obstante, los filósofos de la naturaleza han creído que el hombre fue creado en este estado, porque no han podido entender otra cosa sin la luz de la revelación divina. Del mismo modo que el hombre, contemplado de esta manera, posee una fuerza natural de entendimiento y una facultad de volición que sigue a su razón, así también, posee una parte sensitiva y natural dotada de apetitos irascibles y concupiscibles, como hemos explicado en nuestros Commentaria in primam D. Thomae partem (q. 2, a. 3, r. 4). Por este motivo, el hombre está sujeto a los movimientos de sus fuerzas sensitivas, que pugnan con la razón y soliviantan, inclinan e intentan arrastrar a la voluntad hacia todo lo indecente y contrario a la recta razón". 
sobrenatural, aunque de manera vaga, y dirigir su voluntad libre hacia ella.

Con la ayuda de Dios logra el hombre representarse lo sobrenatural, y con su libre arbitrio está en condiciones de elegirlo. Con esto, Molina reivindica la interpretación agustina sobre la función del intelecto y la voluntad, según la cual la voluntad no permanece pasiva sino libre y activa para elegir (contraponiéndose con ello a Lutero y otros reformadores como Calvino). Por tanto, la gracia depende de la participación activa de la voluntad para ser efectiva:

pero de la misma manera, en relación a los actos sobrenaturales que no pueden realizarse sin auxilio de Dios, es libre [por ejemplo, la voluntad del hombre (N. del A.)] de tal modo que en su potestad está cooperar o no con el auxilio divino o incluso realizar el acto opuesto. Por esta razón, del mismo modo que la existencia de estos actos sobrenaturales [...] dependen del auxilio sobrenatural o de la gracia divina, así también, depende del concurso libre de la voluntad. ${ }^{56}$

5) Por último, el estado de gracia completa consiste en la obtención de la salvación, cuya adquisición es definitiva y consiste en la contemplación de Dios cara a cara.

\section{Limites de la voluntad: contemplar a Dios cara a cara}

Esto sirve a Molina para afirmar que la voluntad es libre en dos sentidos, filosófico y moral. En sentido filosófico, la voluntad es libre cuando cuenta con posibilidades reales de elección entre alternativas, considerando tanto la posibilidad de aceptar o rechazar alguna de ellas como la de actuar o no según la lasitud o energía de cada decisión. En sentido moral, la voluntad es libre cuando sólo puede elegir acompañada de la razón y, por tanto, es la mejor alternativa racionalmente posible, o también en el extraño caso planteado por Molina, cuando se contempla a Dios cara a cara y la voluntad no puede resistirse a amarlo. En este último caso, pese a que se trata de un acto moral, la voluntad no tiene opción ni de permanecer indiferente como tampoco de no amar a Dios. Él lo expresa de la siguiente forma:

5. Segunda: La voluntad no puede no elegir todos sus actos. Ciertamente, la voluntad de aquel que contempla a Dios en esta vida no puede no amar a

56 Molina, Luis de, op. cit., núm. 9, pp. 56 y 57. 
Dios. También a menudo, mientras peregrinamos hacia la beatitud, nos sorprenden determinados actos que la voluntad no puede impedir. De aquí se sigue que la voluntad no asuma la forma de libre arbitrio bajo consideración de cualesquiera de sus actos, sino tan sólo bajo consideración de aquellos que puede no elegir; de este modo, la libertad puede entenderse como acto en ejercicio. De este modo, si la voluntad puede elegir indiferentemente tanto un acto como el contrario, entonces la libertad también podrá reconocerse en relación a la especie del acto que — según se dice — tiene forma de libertad plena y perfecta. ${ }^{57}$

Sin embargo, Molina insiste en que la voluntad permanece libre, incluso en este extraño caso (por ejemplo, contemplar cara a cara a Dios), hasta el momento en que lleva a cabo la elección de actuar. Lo cual quiere decir que, si bien Molina no niega los límites de la libertad (la voluntad puede ser limitada de manera circunstancial debido a las condiciones materiales de cada caso), nunca llega ésta a ser anulada. Molina insiste en la completa disposición de la libertad frente a la elección de actos reales, y en que los únicos casos donde la voluntad no es libre son en los que no interviene en absoluto, como los actos reflejos o involuntarios.

\section{Doctrina de Molina sobre las dos libertades: agustina}

$y$ aristotélica

Por último, y para responder a las dos preguntas ya antes formuladas:

1) ¿Por qué prevalece la libertad de la voluntad en estado de pecado y sin el don de la gracia, cuando no existe la opción de elegir por la salvación?

2) ¿Por qué no halla siempre presente la razón para hacer posible una elección?

Molina analiza primero si la voluntad del hombre es causa segunda de sus acciones, capaz de resistir tentaciones y otras dificultades naturales, sin ayuda de la gracia y con el solo concurso de sus facultades naturales (cum solo concursus generali); y en segundo lugar, en caso de una respuesta afirmativa, si la voluntad en estado natural es libre de cometer buenas obras válidas para su salvación.

57 Véase Molina, Luis, “Disputa II...”, op. cit. 
Molina responde a la primera pregunta en la disputa XIX $^{58}$ y a la segunda en la disputa XXII ${ }^{59}$ con una extensa interpretación de san Agustín. Primeramente, rechaza con nueve argumentos la tesis de la "disposición parcial" del hombre para resistir tentaciones y sortear dificultades naturales. Después, coherente con su interpretación de san Agustín, distingue dos fines de la existencia humana: natural y sobrenatural. El primero significa vivir según la ley natural y su mandato de erigir a la razón en soberana de todas las facultades humanas. El segundo, contemplar a Dios cara a cara; para cada uno de ellos, el hombre cuenta con las facultades y libertades pertinentes: en el primer caso, la libertad innata a la facultad volitiva del hombre, circunscrita a los actos y fines puramente naturales y, por eso, razón suficiente de la moralidad humana. En el segundo caso, la libertad para alcanzar la meta sobrenatural, que incluye tanto el merecimiento personal como el regalo sobrenatural de la gracia divina. Esta última presenta una variante mixta donde cooperan la gracia divina y la voluntad humana para la producción de buenas obras.

Si Molina analiza la consecución de la meta sobrenatural del hombre dentro de la teoría de san Agustín sobre la libertad humana, es porque ésta le permite explicar cómo la meta sobrenatural no puede ser reconocida por la simple luz natural y, consecuentemente, la voluntad del hombre no está en condiciones de elegirla. Pero para explicar la consecución de la meta natural del hombre, echa mano de la tradición aristotélica, porque le permite explicar cómo la meta natural del hombre puede ser reconocida con la luz natural y, consecuentemente, puede aspirar a ella con la sola voluntad libre del hombre (cum solo concursus generali). Esto último representa la capacidad de cada hombre para resistir la tentación de cometer actos opuestos al logro de la meta natural del hombre (por ejemplo, pecados veniales o mortales). Lo que también se aplica a fortiori — como muestra Molina en la disputa XIX - para las acciones morales dentro de condiciones naturales "muy difíciles" (como encontrarse en peligro de muerte).

Si bien en el plano teórico las ideas de Molina sobre el concurso de las facultades naturales del hombre (cum solo concursus generali) resultan suficientes para aclarar los actos morales de cada individuo; en el plano práctico, Dios no niega su apoyo a las voliciones y cogniciones humanas, de tal

58 Molina, Luis de, "Disputa XIX. Sobre las fuerzas del libre arbitrio, sólo con el concurso general, para no sucumbir en cualquier momento a las fuertes tentaciones y para superar cada una de las restantes dificultades puramente naturales”, op. cit., p. 120.

59 Molina, Luis de, "Disputa XXII. En la que explicamos el parecer de san Agustín acerca de la libertad para hacer el bien que perdimos por el pecado del primer padre", op. cit., p. 156. 
forma que actúan conjuntamente tanto la primera como la segunda causa (por ejemplo, Dios y la voluntad del hombre) en dependencia mutua y adaptándose la primera a la naturaleza de la segunda. ${ }^{60}$ Sin embargo, y este debe ser el argumento principal de Molina para bloquear la objeción de pelagiano, vale esto sólo para casos individuales en momentos específicos. Formulado de otra manera: un largo hostigamiento de molestas tentaciones, sumado a la presencia de eventos naturales adversos, quebranta la fuerza natural de cualquier voluntad humana. Por eso, no puede el hombre sin la ayuda de Dios, sin el regalo de la gracia, alcanzar siquiera la meta natural del hombre con absoluta seguridad; tampoco, por supuesto, la meta sobrenatural.

La gracia divina otorga a la voluntad libre la fuerza para realizar obras buenas y evitar cometer actos que atenten contra la salvación del alma, lo que no representa anular su efecto o hacerlo superfluo.

\section{Libertad cum solo concursus voluntatis}

Si bien Luis de Molina no incurre en pelagianismo, sí reconoce importancia a la ponderación racional, condición del libre arbitrio y punto de oposición frente a Martín Lutero. Molina discute la relación entre voluntad y razón cuando refuta las objeciones a su teoría sobre la adjudicación de responsabilidad. Molina escribe:

Por lo demás, considero que la libertad se halla en la voluntad y no en el entendimiento; además, para estar en posesión de la libertad de querer o no querer o de refrenar el acto no queriendo, cuando podemos querer, o queriendo, cuando podemos no querer, no es necesaria por parte del entendimiento toda la deliberación que muchos consideran necesaria y mucho menos el mandato del entendimiento para ordenar a la voluntad que quiera o no quiera o refrene el acto; sin embargo, para querer, basta el conocimiento de alguna bondad que brille en el objeto como algo deleitoso, útil u digno. Ahora bien, si esa bondad no es tan grande y de conocimiento tan perspicuo que infiera una necesidad a la voluntad, como sucede con todas las bondades salvo con la visión pura de Dios, la voluntad puede no realizar el acto libremente, aunque por lo general lo realizará, si es grande y no se presenta nada que la retraiga de esta realización. ${ }^{61}$

60 Sobre el principio de proporcionalidad entre lo que se exige y lo que se puede cumplir, véase Kunz, Karl-Ludwig y Mona, Martino, Rechtsphilosophie, Rechtstheorie, Rechstsoziologie, Stuttgart, UTB, 2006, pp. 47 y ss.

61 Molina, Luis de, "Disputa II...”, op. cit., núm. 9. Molina continúa en este lugar hablando de la elección del mal: "De modo semejante, si le acompaña el conocimiento de 
Con esta declaración se incorpora Molina de lleno a la tradición agustina: la voluntad humana es libre para decidirse por cualquier alternativa particular, incluso considerando los límites impuestos a la libertad por la ignorancia o las situaciones reales. El caso de contemplar a Dios cara a cara in patria constituye una excepción, porque excluye siempre la posibilidad de no amarlo. Y cuando el alma está en vías de alcanzar la visión de Dios, es suficiente una representación vaga para que de esa manera cumpla la condición para la elección y se produzca el acto de voluntad.

La voluntad concebida por Molina decide sin estar condicionada por el conocimiento puntual de aquello que sea el bien; por tanto, ninguna ponderación de la razón sobre los posibles objetos del deseo obliga a la voluntad a hacer una elección determinada, y aun concediendo que esté por la gracia predispuesta a ello, continúa gozando de su libertad de rehusarse. Con lo que siempre estará presente la posibilidad de que la voluntad no haga uso adecuado de la libertad y elija el mal.

\section{Conclusiones: la hora de Dios en el Nuevo Mundo}

Jean Dumont refiere el siguiente pasaje de un memorial dirigido al rey de España Felipe III por los misioneros franciscanos: "Ha llegado ya la hora de Dios. En la cual todos los indios desean ser buenos cristianos. Y así, de muy lejos, vienen a pedir el bautismo [...] Nos ruegan nos quedemos entre ellos [...] nos piden encarecidamente les dejemos puesta una cruz y señalásemos sitio para aquellos a su modo hiciesen iglesias [...] Vienen ofreciéndonos su tierra, su voluntad y su pobreza de comida". ${ }^{62}$

La hora de Dios en el Nuevo Mundo fue un deseo más que una realidad; nunca existió por parte de los pueblos originarios semejante disposición dócil a la conversión: la "conquista espiritual” fue mucho más compleja y

algún mal, la voluntad puede no querer y rechazar el objeto libremente; sin embargo, nada le obliga a no quererlo, porque puede no realizar la nolición refrenando el acto, aunque, cuando el objeto es intenso, por lo general realizará la nolición, salvo que, por otro lado, se le presente algo que la mueva a no realizarla o incluso a preferir algo doloroso en razón de un bien unido a ello. Así pues, si el entendimiento está preparado y en posesión del conocimiento mencionado, la voluntad puede, en virtud de su libertad innata, querer o no querer o no realizar uno ni otro acto, como, hablando del pecado de los ángeles, hemos explicado por extenso - en nuestros Commentaria in primam secundae, q. 9, y también parcialmente en nuestros Commentaria in primam D. Thomae partem - y como a cualquiera le constará por propia experiencia".

62 Dumont, Jean, La hora de Dios en el Nuevo Mundo, Madrid, Encuentro, 1993, p. 9. 
tropezosa. Antes que una conversión tuvo lugar un sincretismo religioso, aún visible en los pueblos originarios de América. Ciertamente los conquistadores, como nunca antes en la historia, cuestionaron su derecho a la conversión forzada. Melchor Cano negó que esa fuera una razón para hacer la guerra, para desposeer de sus posesiones a los infieles, incluso con base en el supuesto del bien superior de la salvación de sus almas.

La conquista planteaba a los juristas salmantinos dos cuestiones capitales: una, sobre el derecho a la conquista del territorio; otra, sobre la subsecuente ocupación y establecimiento de la soberanía sobre las conciencias. Estas eran cuestiones apremiantes de las bulas alejandrinas, y el humanismo jurídico de la Escuela de Salamanca residió en la preocupación de regular, sobre bases justas y adecuadas, la situación de dependencia de la masa de indios sometidos, habida cuenta del sistema de repartimientos y encomiendas que había tomado carta de naturaleza en el Nuevo Mundo y lo expoliaba.

La exposición del concepto de voluntad libre de Molina explicaba la elección de los indígenas en contra de la fe de los conquistadores, porque se puede decir que la voluntad libre es la capacidad, ajena a la necesidad natural, para decidirse tanto por actos conforme a la razón como contrarios a ella. Por eso, la decisión de la voluntad no implica un juicio de la razón, indispensable para la voluntad libre dentro de la tradición aristotélico-tomista. En consecuencia, la simple voluntad no es esencialmente diferente del libre arbitrio, y por tanto, no representan facultades distintas para Molina. Hay una diferencia de grado debido a la situación particular del ejercicio de la voluntad (por ejemplo, antes o después del pecado original, antes o después de recibir la gracia, antes o después de contar con el uso de razón), pero la voluntad goza siempre de completa libertad de elección, lo que posibilita al hombre para optar por las buenas como por las malas obras, sea se le considere en estado de caída o con el don de la gracia. El interés predominante por las cosas temporales, producto de la confusión racional del pecado original, sumado a la autonomía de la voluntad respecto de la razón, explican — según Molina- los actos contra la razón y elección del mal. Si esto no anula la responsabilidad moral (si el hombre puede hacer juicios morales, y asignar méritos y culpas), es porque la volición del agente posee siempre la capacidad de unir su elección al juicio de la razón y decidirse por lo mejor. 